\title{
Time, space, and episodicity of physical disturbance in streams
}

\author{
Daniel Miller ${ }^{\mathrm{a}, *}$, Charlie Luce ${ }^{\mathrm{b}}$, Lee Benda ${ }^{\mathrm{c}}$ \\ ${ }^{a}$ Earth Systems Institute, WA 3040 NW 57th Street, Seattle, WA 98107, USA \\ ${ }^{\mathrm{b}}$ Boise Aquatic Sciences Lab, Rocky Mountain Research Station 316 E. Myrtle, Boise, ID 83702, USA \\ ${ }^{\mathrm{c}}$ Earth Systems Institute, CA 310 N Mt. Shasta Blvd., Suite 6, Mt. Shasta, CA 96067, USA
}

\begin{abstract}
Storm-driven episodes of gully erosion and landsliding produce large influxes of sediment to stream channels that have both immediate, often detrimental, impacts on aquatic communities and long-term consequences that are essential in the creation and maintenance of certain channel and riparian landforms. Together, these effects form an important component of river ecosystems. In this paper, we describe issues involved in characterizing and predicting the frequency, magnitude, spatial extent, and synchrony of these sediment influxes. The processes that drive sediment fluxes exhibit spatial and temporal variability over a large range of scales. Disregard of this variability can have unanticipated consequences for efforts to quantify process rates, as we illustrate using landslide densities observed for a storm event in western Oregon. Multiple factors interact to create the temporal and spatial patterns of erosional and mass-wasting events that affect stream channels. Fires, in particular, enhance susceptibility to erosional and mass-wasting processes, and thus affect the timing and magnitude of sedimentmobilizing events. We use examples from west-central Idaho to show how fires, storms, and topography interact to create spatially distinct patches of intense erosional activity. We require quantitative descriptions of these controlling factors to make quantitative predictions of how differences or changes in topography, fire regime, and climate will affect the regime of sediment fluxes. The stochastic and heterogeneous nature of these factors leads us to quantify them in probabilistic terms. The effects of future fire and storm sequences are governed in part by the past sequence of events over time frames spanning centuries and spatial extents spanning entire river basins. Empirical characterization of past events poses a considerable challenge, given that our observational record typically spans several decades at most. Numerical models that simulate multiple event sequences provide an alternative means for estimating the influence of antecedent conditions and for quantifying the role of different controlling factors.
\end{abstract}

(C) 2003 Elsevier Science B.V. All rights reserved.

Keywords: Aquatic habitat; Fire; Landslides; Erosion

\section{Introduction}

Intense or extended rainfall can trigger surface erosion and landsliding (Caine, 1980) that bring large and sudden pulses of sediment and organic debris to

\footnotetext{
* Corresponding author. Tel.: +1-206-633-1792; fax: +1-425-671-0094.

E-mail address: danmiller@earthsystems.net (D. Miller).
}

stream channels. These events can substantially impact channel and riparian habitats. Landslides, debris flows, and consequent debris torrents can scour channels to bedrock and destroy riparian vegetation (Hack and Goodlett, 1960; Benda, 1990; Nolan and Marron, 1990; Cenderelli and Kite, 1998; May, 1998); local deposition from landslides and debris flows can bury or block channels (Nolan and Marron, 1988), create log jams (Hogan et al., 1998), and potentially 
create conditions conducive to dam-break floods (Coho and Burges, 1993); sediment introduced by mass wasting and extensive gully erosion can alter channel characteristics both locally and over many kilometers, with effects that include channel widening, reductions in pool frequency, fining of bed texture, and increased turbidity (Coates and Collins, 1984; Everest et al., 1987; Nolan and Marron, 1990; Harvey, 1991; Madej and Ozaki, 1996; Montgomery and Buffington, 1998).

Although these impacts can be detrimental to aquatic communities, the erosional and mass wasting events that trigger them are also recognized as integral to the creation and maintenance of certain types of channel habitat. Landslides and debris flows bring boulders and large woody debris that provide longterm sources of channel roughness and complexity (Everest and Meehan, 1981; Benda, 1990; Grant et al., 1990; Wohl and Pearthree, 1991; Grant and Swanson, 1995), large, transient increases in sediment supply create berms, terraces, and fans that shape the valley floor (Benda, 1990; Madej, 1990; Nakamura et al., 1995) and create side channels and riparian surfaces (Miller and Benda, 2000).

The impacts of erosional and mass-wasting events evolve over time as fluvial transport moves and resorts channel-stored sediment, debris jams decay, riparian vegetation regrows, and large woody debris is recruited to channels (Benda, 1990; Nolan and Marron, 1990; Grant and Swanson, 1995; Hogan et al., 1998; May, 2001; Pabst and Spies, 2001). Conditions encountered in channels subject to pulses of sediment input and transport thus depend on where in time one intersects this trajectory of change. The population of sub-basins and tributary channels that constitute a drainage basin provides many separate and potentially independent sediment sources. Asynchronous activation of these sources produces a population of channel reaches at different points along the post-event trajectory of channel evolution (Benda et al., 1998). The past sequence of sediment influx and transport events thus acts to create and enhance spatial heterogeneity in channel conditions (Benda et al., this issue) and contributes to habitat complexity. Regionally, the mosaic of habitat conditions created by the sequence and spatial distribution of these events forms an important component of riverine ecosystem structure (Reeves et al., 1995).
Fires play an integral role in the timing and severity of erosional and mass-wasting events (Swanson, 1981; Meyer et al., 1995; Cannon, 2001; Istanbulluoglu et al., 2002). Fires can destroy ground cover, reduce soil infiltration capacity, and kill vegetation, all of which increase the potential for rainfall-triggered erosion and mass wasting (Wondzell and King, this issue). These effects are greatest immediately post-fire and tend to dissipate over several years, although firerelated loss of root strength and the associated susceptibility to landsliding may persist for a decade or more (Meyer et al., 2001). Thus fires and storms act together to drive sediment fluxes over a landscape. The sequence of sediment inflow and transport events occurring within a river basin arises from the interacting sequence of fires and storms (Benda et al., 1998). The impacts to stream channels vary over time, depending on where they are within this sequence. Other processes, such as disease, windthrow, and snow avalanches, can also alter vegetation cover and affect susceptibility to surface erosion and mass wasting, but fire is the predominant source of vegetation disturbance in many landscapes (Agee, 1993).

Storm-driven surface erosion and mass wasting, accentuated by fire, generate large inputs of sediment and organic debris to channel systems that are punctuated in space and time (Benda and Dunne, 1997b). These inputs act to alter the suite of channel and riparian habitat types and quality found in a basin, adding to the dynamic and heterogeneous elements of the river environment. These elements have characteristic temporal and spatial scales that are governed by the frequency and magnitude of the sediment inflows, which in turn are governed by the periodicity, magnitude, and timing of fires and storms, modulated by rates of sediment production (Benda and Dunne, 1997a).

The regime of sediment inflows can be difficult to characterize, in part because of the extended periods that may separate large-magnitude events (Kirchner et al., 2001). Yet, as discussed above, this regime forms an integral component of a river ecosystem (Reeves et al., 1995; Gresswell, 1999), and any changes to that regime pose consequences that are largely unknown. To anticipate the effects of natural and anthropogenic change in fire and climate on stream environments, we must characterize the effects those changes have on the frequency and magnitude of 
sediment influxes and the impact of those influxes on channels. Benda et al. (this volume) approach the second topic; here we address the first.

Unfortunately, data to directly quantify the controls on frequency and magnitude of sediment fluxes are limited, in large part because of the long periods involved, so that our understanding of these processes is largely qualitative and based on inference. Meyer and Pierce (this volume), show that erosional regimes have changed over time concurrent with climatic shifts, but we do not yet have quantitative models to predict how current and future changes in climate and fire regime will alter the timing and magnitude of erosion events. Indeed, it is difficult to quantitatively characterize current erosion regimes. Erosion and mass-wasting processes are unevenly distributed in time and space, which creates a particular challenge for empirical characterization, as we illustrate using measures of landslide density in coastal Oregon. Multiple interacting processes drive erosion and mass-wasting events, which complicate attempts to characterize the factors controlling their occurrence. As an example, we look at how patterns of stream disturbance depend on the timing and spatial coincidence of fires and storms and at how topography and storm characteristics interact to control the spatial distribution of landslides in west-central Idaho. Finally, we briefly discuss methods for quantifying these processes and describe the use of numerical models for characterizing the controls on sediment flux.

\section{Scale relations and sources of variability}

Landslides and debris flows are an important mechanism for storm-driven pulses of sediment delivery to channels in many landscapes (Hack and Goodlett, 1960; Larsen and Simon, 1993; Benda and Dunne, 1997b; Hovius et al., 1997) and characterization of landslide rates is a key component in efforts to quantify effects of land management on erosion regimes (Sidle et al., 1985; Montgomery et al., 2000; Brardinoni, 2001). In February 1996, a high-intensity, long-duration storm triggered landsliding and flooding across western Oregon. Rainfall intensities and flood peaks exhibited great spatial variability (Taylor, 1997a); estimated return intervals for flood peaks in the area spanned a range from less than 10 to over
100 years (Bush et al., 1997). Several studies examined the effect of forest cover and land management on landslide densities associated with this storm (Bush et al., 1997; May, 1998, 2002; Robison et al., 1999). Although these studies did not include fire-related landslides, the results are still instructive.

These three studies reported a large range in observed landslide densities, arising in part from large spatial variability in storm intensity and from differences in the study methods. Bush et al. (1997) relied on landslides identified on 1:24,000-scale aerial photographs, whereas Robison et al. (1999) and May $(1998,2002)$ used field surveys to locate landslides and debris flows that reached stream channels. The study of Bush et al. (1997) encompassed an area exceeding $4000 \mathrm{~km}^{2}$ including the Siuslaw National Forest (SNF) and surrounding areas; the Robison et al. (1999) study involved six sites in western Oregon following the February storm encompassing an area of almost $83 \mathrm{~km}^{2}$; May's survey sites involved 11 third- to fifth-order streams in the Siuslaw Basin with a combined area of $47 \mathrm{~km}^{2}$. Each survey resulted in different relationships between relative landslide density and forest-stand type. All studies found the highest average densities in clearcut areas harvested within the last decade. Results differed substantially, however, for the relative density of landsliding between second-growth and older stands. Robison et al. (1999) consistently found higher densities in stands older than 100 years, whereas May (2002) consistently found higher densities in second-growth stands (Table 2, p. 1103). Bush et al. (1997) did not differentiate between second-growth and older stands. These differences illustrate the difficulty in characterizing a heterogeneous entity and provide an opportunity to look at how the scale of measurement can affect such observations.

The Coastal Landscape and Analysis Study (CLAMS; http://www.fsl.orst.edu/clams/) used data from Bush et al. (1997) and Robison et al. (1999) to derive regionally applicable estimates of landslide susceptibility as functions of forest-cover type for the Coast Range of Oregon. To examine the effects of sampling scale, the Bush et al. (1997) inventory (Fig. 1) was subsampled with replacement (a bootstrap sample, e.g. Chernick, 1999) at a variety of scales with landslide densities calculated as a function of forest type for each sample. Forest type was evaluated 


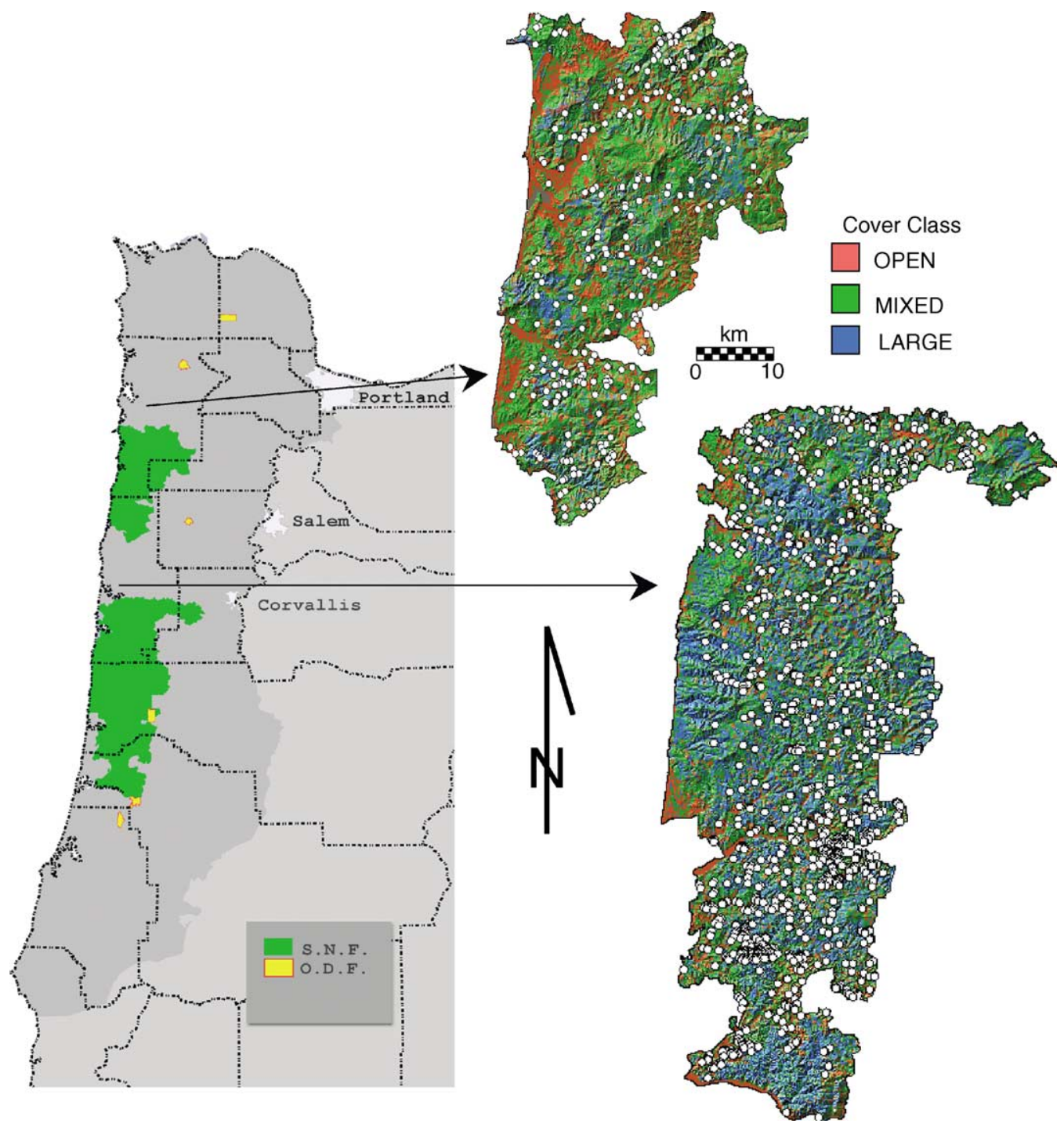

Fig. 1. Landslide-inventory sites used for evaluating scale effects on landslide density. The SNF study (Bush et al., 1997) encompassed over $4000 \mathrm{~km}^{2}$ in two blocks, indicated by the green polygons on the map of western Oregon. The yellow polygons indicate the study sites included in the ODF study (Robison et al., 1999). Landslide locations mapped in the SNF study are shown with white dots on the shaded relief images to the right. Forest-cover types described in the text are indicated by color.

using the CLAMS vegetation coverage (Ohmann and Gregory, 2002), with forest classes grouped into three broad categories: (1) OPEN, consisting of recently clearcut and unforested land, (2) MIXED, consisting of forest cover of predominately small conifers or forests with a predominance of hardwoods, and (3) LARGE, forest cover consisting predominately of large conifers. A fourth class for roads was also included in the CLAMS study, but is not used for our analysis. Data from Robison et al. (1999) were used to estimate bias in density estimates arising from the inability to see small landslides under tree canopy in aerial photographs (Pyles and Froehlich, 1987; Brardinoni, 2001) and to account for spatial variability in topographic control on landslide susceptibility (Miller et al., 2002). 


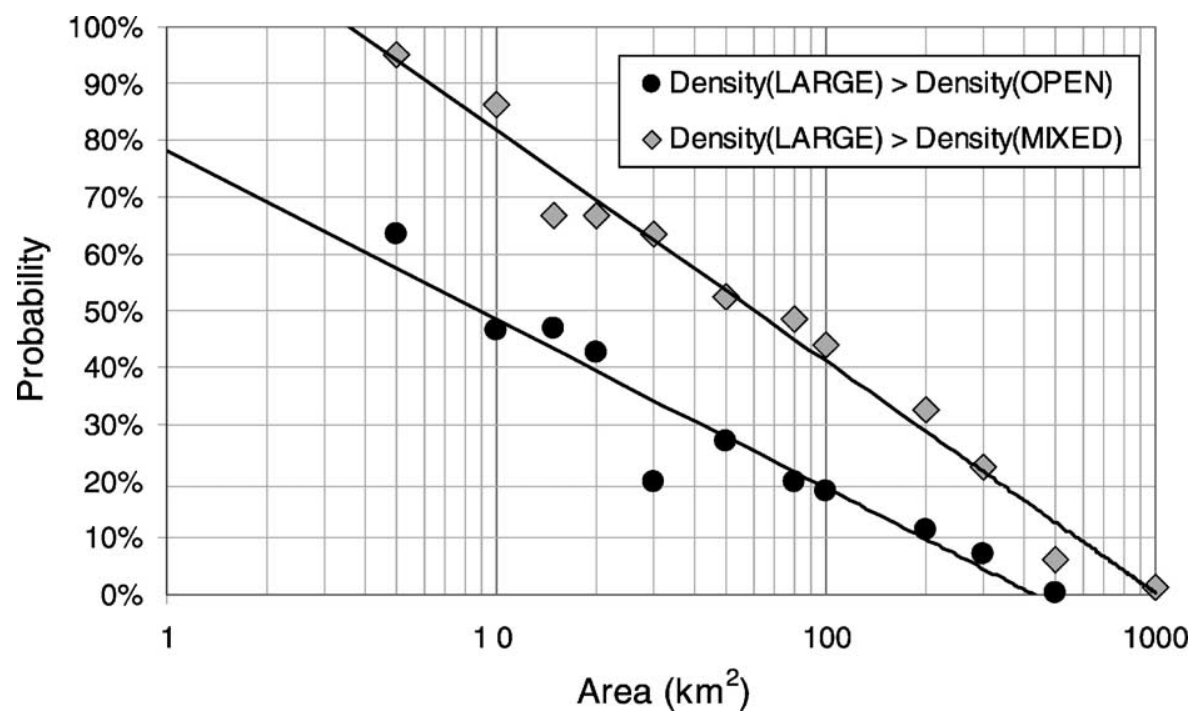

Fig. 2. The landslide inventory from the SNF study (Fig. 1) was subsampled over a range of scales. For any contiguous sample block containing landslides in more than one cover type, the probability that landslide density in the "LARGE" cover type is greater than that in either the "OPEN" or "MIXED" cover types varies as a function of the size of the sample block.

We found that the relative landslide density between these three cover types varied as a function of scale. For sample areas spanning tens of square kilometers, there is a high probability that observed landslide density is highest in the LARGE cover type (Fig. 2), as observed by Robison et al. (1999). But at scales of hundreds of square kilometers, observed densities are almost always lowest in the LARGE cover type.

This dependence on sample scale arises in part because the sample area is smaller than the characteristic scale of heterogeneity in the spatial distribution of landslides, a concept related to the representative length in continuum mechanics (e.g. Middleton and Wilcock, 1994) and the elementary unit volume in fluid dynamics (Bear, 1972). We found that the range of observed landslide densities varied as a function of the area sampled (Fig. 3). A large range in densities is found for small sample areas, with a large proportion of the samples containing no landslides at all. Two changes occur as the sample area increases: excluding zero values, both the range and modal value of observed landslide densities asymptotically decrease. The decrease in modal value (Fig. 3) occurs because about $20 \%$ of the samples - those with zero values, primarily small sample areas-are excluded. Similar biasing occurs with field studies, because site surveys and resulting conclusions focus on areas that have landslides. With all samples included, the modal value remains constant with sample area. If the sample area is small, there is a probability of observing a high landslide density. If the area covered by one particular cover type in a sample tends to be smaller than the others, there is a probability of finding a higher landslide density in that cover type solely because of the differences in area.

Excluding roads, the Bush et al. (1997) study area included 21\% in the OPEN class, 55\% in the MIXED class, and $24 \%$ in the LARGE class. Robison et al.'s (1999) six sites included $17 \%$ in age classes less than 10 years, $61 \%$ in age classes from 10 to 100 years, and $22 \%$ in age classes exceeding 100 years. May's (1998, 2002) sites included $23 \%$ in clearcut units, $47 \%$ in second-growth stands, and $30 \%$ in mature forests. This difference in area between cover types may account for the behavior observed for the MIXED and LARGE classes (Fig. 2), because most samples have a smaller proportion of their area in the LARGE class. It does not explain the relationship between the OPEN and LARGE classes, however, since these two classes involve similar areas. This suggests that the length scale required to average variability in the LARGE cover class is greater than for the MIXED class, 

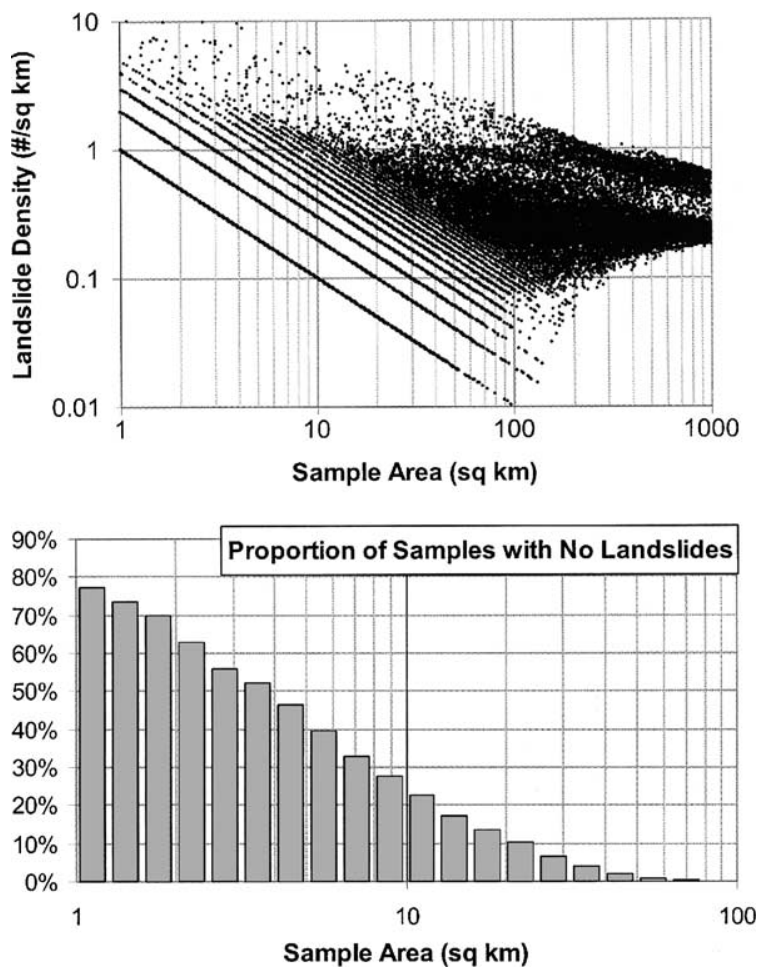

Fig. 3. The upper graph is a scatter plot of landslide densities from 50,000 randomly placed sample blocks within the two SNF study areas shown in Fig. 1. Densities are shown for the entire sample block with no separation of cover type. The slanted arrays of aligned dots correspond to samples containing one landslide (the lowest, left-most array), two landslides, and so on. About $20 \%$ of the samples had no landslides. The proportion of samples with no landslides is shown as a function of sample size in the lower graph.

although other unexplored sampling issues may be involved.

These results show that landslides are found in dense clusters over tens of square kilometers with large intervening areas containing few landslides. They also suggest that landslides tend to be clustered more tightly in old forests and more evenly distributed in other forest types. Conclusions regarding the influence of vegetation on landslide susceptibility may thus vary dramatically depending on the scale of observation. The large scale of heterogeneity that must be accommodated complicates characterization of landslides and other sediment-moving events.

The scale effects described above result from variability in the attributes being measured, which in this case are landslide locations. Many factors create variability in the production and delivery of sediment to stream channels. Observed differences in the spatial density of landslides are explained in part by variations in geology, topography, and vegetation (e.g. Dragovich et al., 1993a,b). Such controls can be quantified and, and to the extent and resolution that they are mapped, their relative effect on landslide rate can be anticipated, as is done for landslide-hazard mapping (e.g. Hammond et al., 1992).

There are other factors whose influences on landslide location are unknown a priori. Spatial variability in storm characteristics provides an example. The storm in February 1996 that triggered the landslides mapped in Oregon, although regionally extensive, exhibited large variability in rainfall intensity (Oregan State University, 1996; Taylor, 1997b, see also http:// www.ocs.orst.edu/gifs/flood_map.GIF). Convective storms can also generate local high-intensity cells over spatial scales of kilometers. Spatial variability in storm intensity thus creates heterogeneity in sediment production rates over scales spanning distances from one to hundreds of kilometers.

The distribution of soil depths poses another unquantified source of variability in factors controlling sediment production (Dunne, 1998; Schmidt, 1999). Soil depth is an essential factor in stability of hillslope soils (Hall et al., 1994) and in setting the volume of sediment available for delivery to a channel system (Benda and Cundy, 1990). The spatial distribution of soil depth over any area, coupled with the future sequence of fires and storms, determines in part the number of landslides that will occur within that area over any specified period of time. If a series of storms triggers a large number of landslides that evacuate the soil from landslide-prone hollows, the distribution of soil depths is changed along with the potential for future landsliding. The spatial distribution of soil depth and the potential for sediment delivery to the channel system is thus a function of past events (Benda and Dunne, 1997b). Given the time scales involved for colluvial refilling of hollows (Dietrich and Dunne, 1978; Reneau et al., 1990), that history may span many centuries. The past sequence of storms, fires, and other vegetation disturbances, such as disease and windthrow, create a mosaic of soil properties with variability over scales spanning meters to hundreds of kilometers.

Our recourse in dealing with effects of stochastic and heterogeneous processes like storms and fires is to 
characterize them empirically in terms of probability distributions. The use of probability distributions is well established for estimating storm intensities and peak flows for specific intervals of time. We can do the same with patterns of spatial heterogeneity in sediment production arising from unquantified sources, such as potential variations in soil depth. For example, soil geotechnical properties are variable over scales affecting individual landslides and gullies and probabilistic descriptions of soil properties are used in estimates of slope stability (Hammond et al., 1992).

\subsection{Stochastic interactions: temporal-spatial correlations}

Stochastic erosional drivers acting over a heterogeneous topography create an erosion regime characterized by episodic patches of activity. The size and location of these patches depends on the interactions of fires, storms, and topography, which we illustrate here with examples from central Idaho. The Boise National Forest has experienced numerous large fires over the last century (Fig. 4). During the last 12 years, fire intensity, measured by crown scorch, was mapped from the air for several of these fires. Over this time period, landslides, gully erosion, and evidence of stream disturbance were also mapped from 1:15,800-scale aerial photographs (Fig. 5). Mapped patch sizes for variations in fire intensity have length scales on the order of $1-5 \mathrm{~km}$. These fires had a decidedly non-uniform influence on patterns of mass wasting and associated channel disturbance. The "patches" of stream disturbance are individually larger than the patches of high-intensity burn; stream disturbances may initiate within high-intensity burn patches and then propagate through lower-intensity burn and unburned areas.

Disturbed channels concentrated in patches with length scales on the order of 5-10 km are also evident (Fig. 5). These patches cluster in and near recent fires, but several fall outside burned areas. Examination of event timing reveals a mixture of causes. At large (between group) scales, much variability is explained by whether or not a severe weather event struck the area. One particularly large thunderstorm in summer 1996 (prior to the aerial photography) affected several streams just slightly north and west of the center of the basin. The cluster in the southwestern part of the basin was affected primarily by a thunderstorm in 1993, shortly after the fire. Although not shown on this map, the 1 January, 1997 rain-on-snow event affected patches in the southwestern part of the basin again, and several streams immediately north of the mapped area in an area burned in 1989. The clustering in these groups is similar to that seen in Fig. 5. All affected streams were below $1500 \mathrm{~m}$ in elevation. Variations in burn intensity explain only part of the controls on mass wasting in individual basins in the area of that storm. The debris flow on the far-eastern side of the basin resulted from a small thunderstorm centered over one flank of the basin. After the event, one could walk across a hillslope with relatively uniform burn severity and see the erosional response change from severely eroded to undisturbed within $500 \mathrm{~m}$ although no variation in fire severity (as measured by soil characteristics) was observed over that transect. These observations suggest that the scale of variability in the driving weather exerts a strong control on the spatial extent of subsequent erosion.

It is useful to compare the patch size of stream disturbance seen in these examples to the size of habitat patches used by fish (Fig. 6). Variations in summer water temperature are the hypothesized source of fragmentation for bull trout (Salvelinus confluentus) in this basin, which yields elevation as a control on the distribution of spawning and rearing habitat (Dunham and Rieman, 1999). Dunham and Rieman (1999) found that larger patches were more likely to be occupied, in part because larger patches yield larger, more diverse, more stable, and betterconnected populations of fish. Smaller patches are also at risk of losing all of their habitat to mass wasting or channel disturbance during a single event, whereas a coherent set of disturbances over a patch the size of the larger basins has not been seen in the last 15 years, although fires of a size large enough to cover several habitat patches are not unusual in the historical record. If the spatial extent of stream disturbances are controlled more by the intersection of fire and weather than by the occurrence of fire alone, then fire alone is unlikely to cause extirpation of more than one or a few local populations during a given fire episode.

Interactions between climatic events and topography also play an important role in setting the patch scale over which erosional events are concentrated. For example, the distribution of landslides mapped by the Payette National Forest following a rain-on-snow 


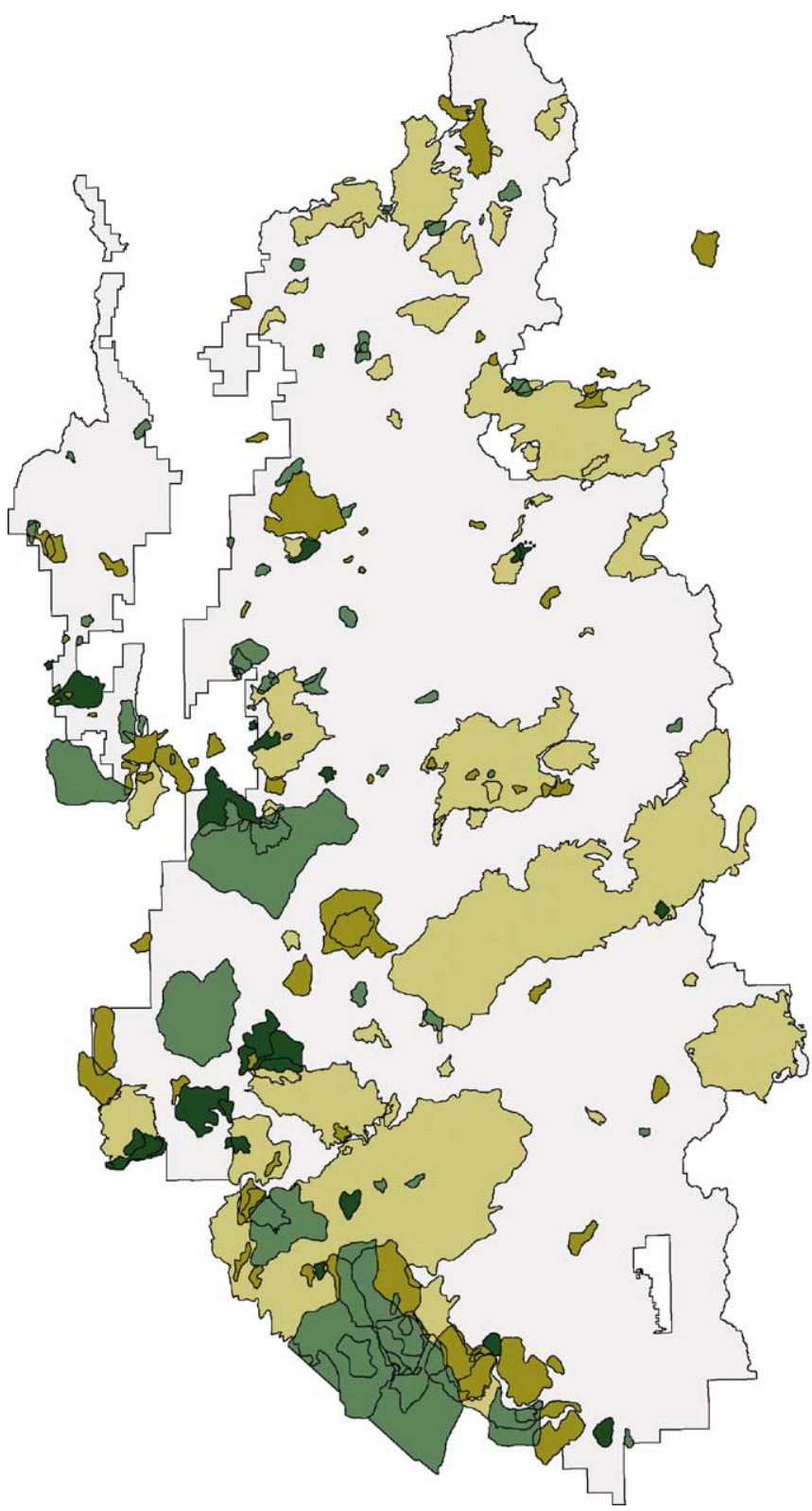

Fire Year Categories
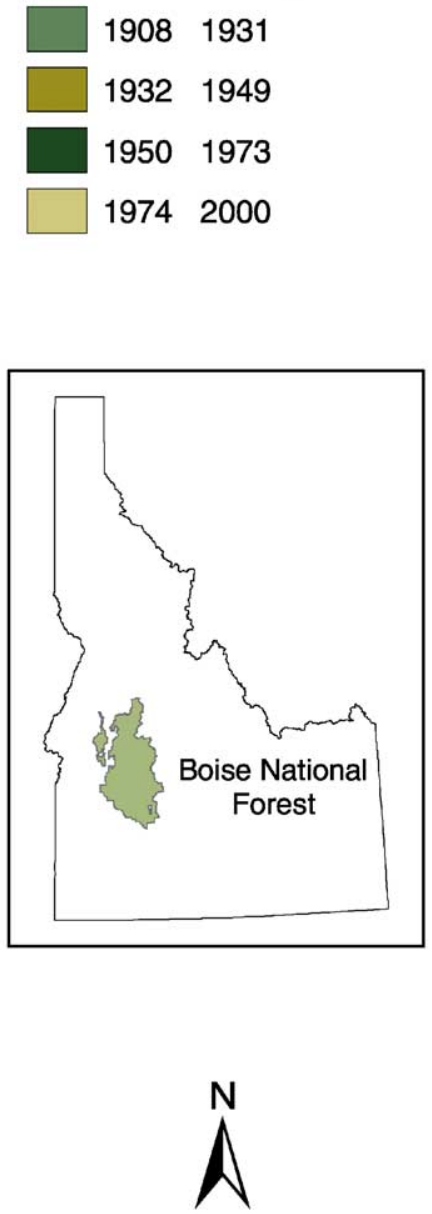

$\begin{array}{lllll}0 & 10 & 20 & 30 & 40\end{array}$

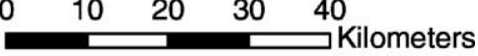

Fig. 4. Fires over 100 ha mapped since 1908 on the Boise National Forest. Some areas have burned up to five times during that period.

event in January 1997 revealed that elevation was influential (Fig. 7). Most (94\%) of the landslides were between elevations of 1000 and $1500 \mathrm{~m}$. Focusing on this elevation range, $87 \%$ of these landslides occurred on slopes steeper than $27^{\circ}$ (estimated from a DEM). Here we see a relatively uniform storm, a large synoptic system with high spatial correlation in precipitation, coming over complex topography to form a distinct pattern in geomorphic response.

\subsection{Controls on event occurrence}

To quantify relationships of cause and effect on the frequency and magnitude of stream disturbance 


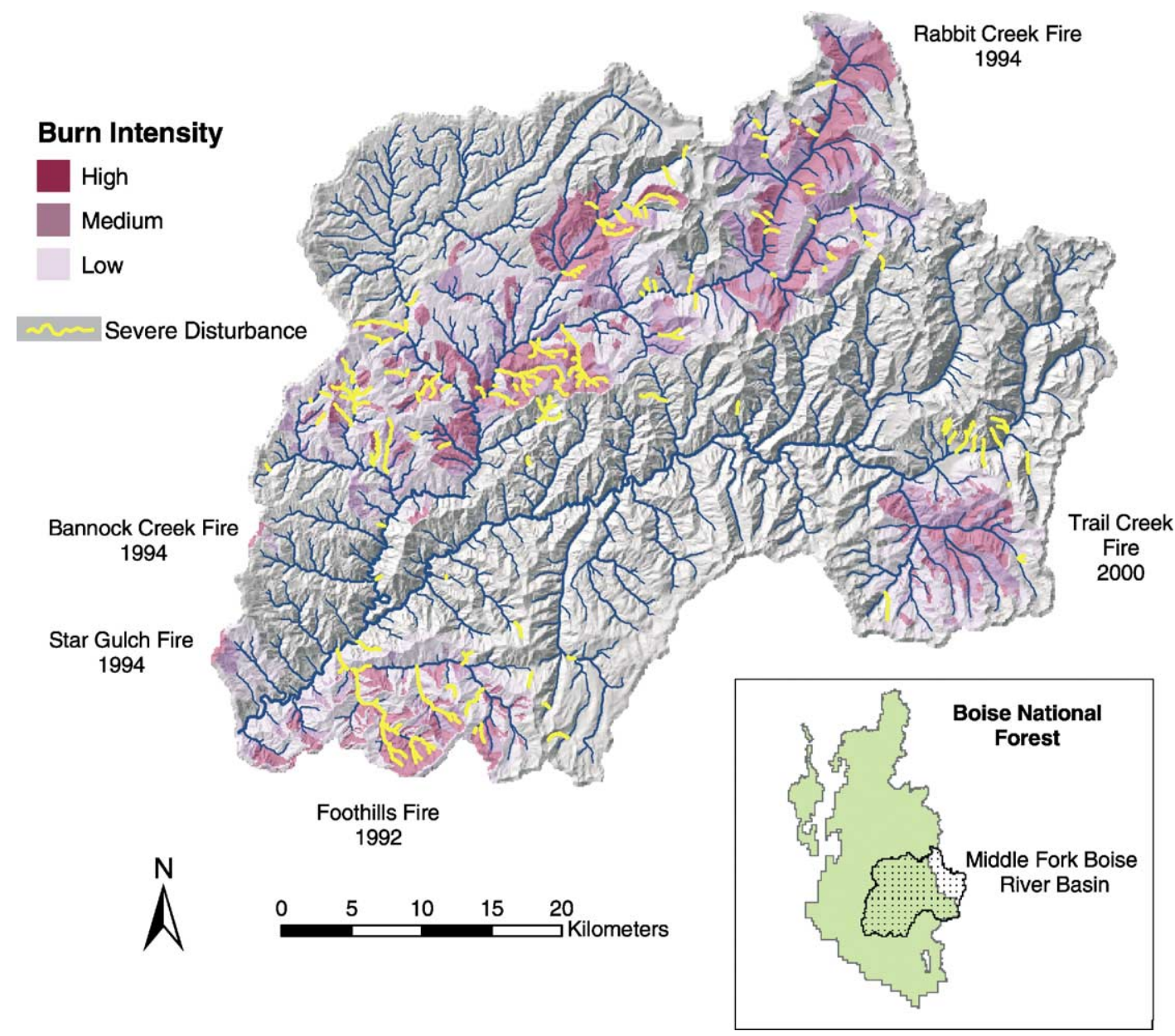

Fig. 5. Middle Fork Boise River basin showing fires since 1989 and streams with evidence of major bed disturbance. Estimates of fire intensity are based on extent of crown scorch and disturbed channels are mapped from aerial photographs.

caused by sediment-moving events, it is useful to define a conceptual model of the processes involved. From the discussion above, and capitalizing on work by Benda and Dunne (1997a,b; further described in Benda et al., 1998), we identified three primary components:

(1) A spatial template imposed by topography, bedrock lithology, geologic structure, and soil type that controls locations of sediment production and storage and sets points of delivery to the channel system.

(2) A set of stochastic temporal drivers that alter erosional susceptibility and trigger sediment fluxes, e.g. fires and storms.
(3) The antecedent sequence of events, which with the rate of sediment production, determines the volume of sediment available for delivery to and transport through the channel system.

These three concepts provide a framework with which to interpret and anticipate differences in disturbance regimes, but to be useful in quantifying any differences, we must develop quantitative characterizations of each component and of interactions between them. We describe strategies for characterizations of topography, fire regime, and storm climate in the following sections. Characterization of the antecedent sequence of events, or at least of their consequences, poses a considerable challenge. 


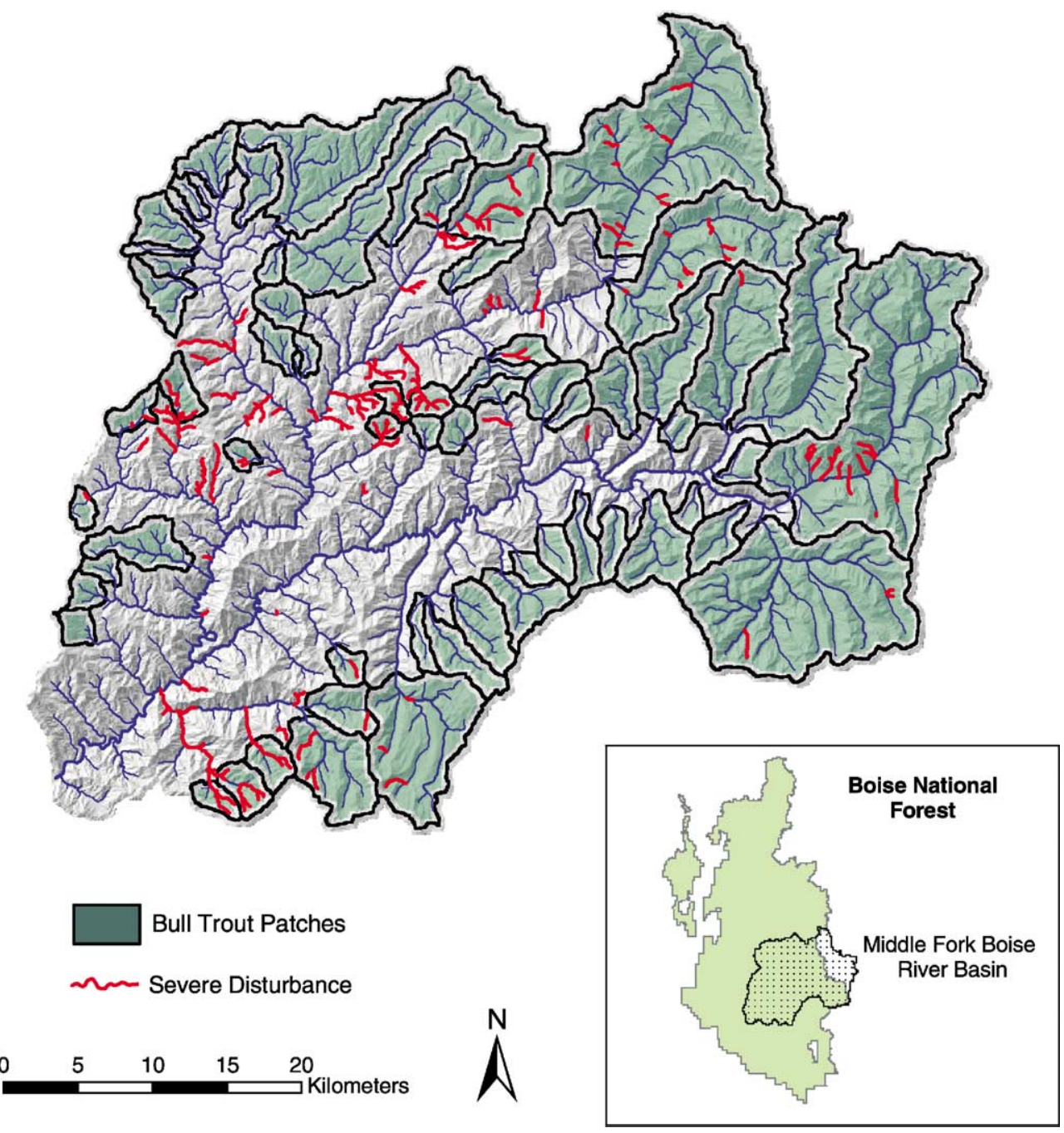

Fig. 6. Channels with major channel disturbance events since 1989 in the Middle Fork Boise River basin juxtaposed with bull trout habitat patches (after Dunham and Rieman, 1999).

For example, we have no means for efficient highresolution measurement of soil depths over watershed scales. Likewise, the large temporal and spatial scales involved hinder quantification of process interactions. In the final section, we discuss use of numerical models as a means of addressing these issues and as a tool for exploring the role of different factors in controlling the frequency and magnitude of sediment fluxes.

\subsubsection{Topography}

Topographic attributes represent large controls on susceptibility to mass wasting (e.g. Dietrich et al., 2001) and surface erosion (Dietrich et al., 1992). Topography also determines where in the landscape colluvium will accumulate (Hack and Goodlett, 1960; Dietrich and Dunne, 1978) and dictates the points of delivery for water-eroded and mass-wasting derived sediment to the channel network (Swanson et al., 1988; Benda and Dunne, 1997b). The advent of digital elevation data and a variety of tools and algorithms for using it (e.g. Zevenbergen and Thorne, 1987) make spatially distributed estimates of topographic attributes straightforward. Coupled with field observations of erosional processes, topographic data can be used to 


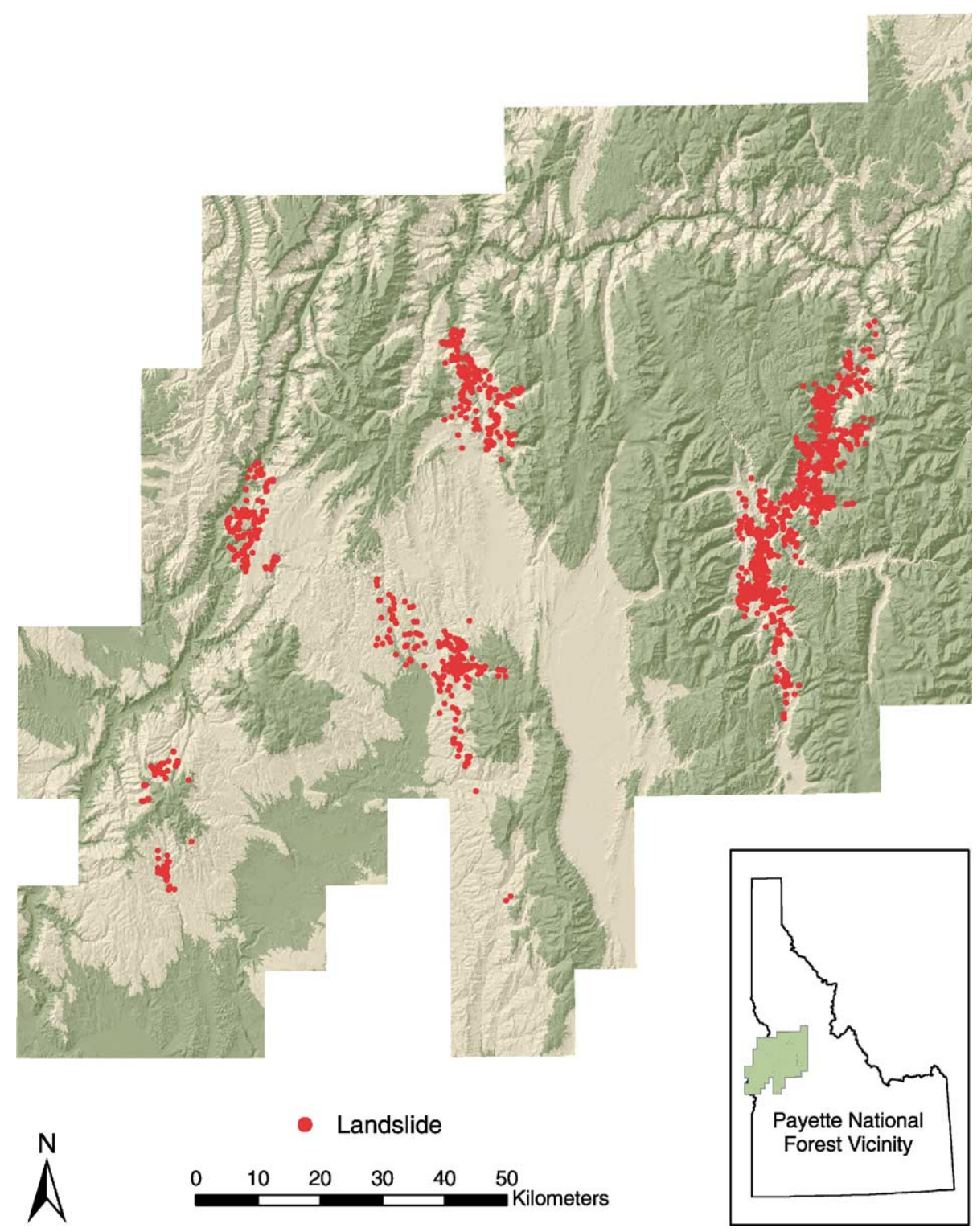

Fig. 7. Landslides following January 1997 rain-on-snow event within study areas in the Payette National Forest. Lighter shading indicates areas between 1000 and $1700 \mathrm{~m}$ elevation.

constrain the probability of erosional inputs to channel systems (Istanbulluoglu et al., 2002).

We illustrate these concepts using an example for debris flows in the Oregon Coast Range, based on work done with Coastal Landscape and Analysis Study (http://www.fsl.orst.edu/clams/). Although this example deals with a particular mass-wasting process, the techniques are applicable to any topographically controlled erosional process.

It is convenient to separate topographic controls on debris-flow occurrence between those that affect initiation and those that affect the downslope scour, transport, and deposition of material. Debris flows are often initiated by shallow landsliding of colluvial 
material accumulated in topographic hollows (Dietrich and Dunne, 1978). Stability of shallow colluvial deposits can be estimated using a simple modelthe infinite slope approximation-with a topographic dependence on slope gradient alone (e.g. Hammond et al., 1992). Shallow landslides are triggered by increased pore-pressure gradients during periods of intense precipitation (Caine, 1980), which can be estimated as a function of rainfall intensity, upslope contributing area, and local slope (O'Laughlin, 1986). These two models point to local surface gradient and specific contributing area as primary topographic controls on shallow landsliding (Montgomery and Dietrich, 1994). Iverson (2000) highlights limitations to the hydrologic assumptions used in this model, but still recognizes the importance of local slope and specific contributing area in setting the antecedent soil moisture conditions that modulate the impact of transient periods of high-intensity rainfall on slope stability. We thus use a function of local slope and specific contributing area (that of Montgomery and Dietrich (1994), with soil parameters held uniform), as a topographic index of slope stability. Using landslide inventories, this index can then be calibrated as a function of relative landslide density. This provides a spatially distributed estimate of topographic control on susceptibility to shallow landsliding and associated debris-flow initiation.

Once initiated, subsequent downslope travel distance of a debris flow can be parameterized in terms of several topographic attributes. Benda and Cundy (1990) identified channel gradient and channel junction angles along the debris-flow track as dominant controls. CLAMS (Miller et al., 2002) has expanded on their work to include cumulative scour and depositional length as a proxy for debris-flow volume (Iverson et al., 1998; May, 2002) in a probabilistic model of debris-flow runout. This model was calibrated using field mapping done by the Oregon Department of Forestry (ODF) following the 1996 storms (Robison et al., 1999) in the Oregon Coast Range.

Coupling probability estimates of landslide initiation and debris-flow runout provides an estimate for the probability of debris-flow delivery of material to a channel (Fig. 8). For example, in the Siuslaw River basin in coastal Oregon, topographic differences between Knowles Creek basin, to the east, and Sweet Creek basin, to the west, result in large differences in the predicted probability of debris-flow delivery between these two channel systems. Large variability exists even within smaller sub-basins within each system. We expect that such differences in the topographic controls on debris-flow behavior between basins will affect the frequency and magnitude of sediment delivery to the channel system, with consequences for the frequency of habitat-altering disturbances within each basin. Variations in the frequency and magnitude of debris-flow events may also be manifest in current distributions of channel and valley floor morphologic attributes (Benda, 1990; Wohl and Pearthree, 1991) and in the size of debris-flow fans (May, 2001), providing a means for empirical verification of such hypotheses.

\subsubsection{Fire}

Myriad processes affect fire behavior, resulting in complex patterns of fire occurrence over space and time (Agee, 1993). Efforts to mechanistically model fire behavior require large inputs of empirical data (Keane et al., 1996), more perhaps than are feasible for the large-scale (McKenzie et al., 1996) and long-term models needed to characterize fire effects on erosion and mass-wasting regimes. Simple characterizations of fire occurrence covering basin to regional scales and spanning centuries can be expressed in terms of the mean rotation interval, a distribution of fire sizes, and initiation frequency. Numerical models incorporating stochastic aspects of fire size and ignition can then be used to simulate fire sequences (Agee and Flewelling, 1983). From this basis, a variety of other controlling factors can be included in long-term models. For example, Benda and Dunne (1997b) included increased ignition probability following fire, Wimberly (2002, see also Wimberly et al., 2000) included variable burn severity, and Benda et al. (1998; see also USDA Forest Service, 2002) included topographic controls on fire spread. The primary constraints for use of such models are availability of data to characterize the controlling factors.

Estimates of fire rotation can be made from dendrochronology of fire scars (e.g. Agee et al., 1990) and stand-age distributions (Van Wagner, 1978), both of which depend on the age distribution at the time of observation. Using a fire-simulation model, Wimberly et al. (2000) showed that stand-age distributions can vary dramatically over time with a range of variation that is a function of the area observed 


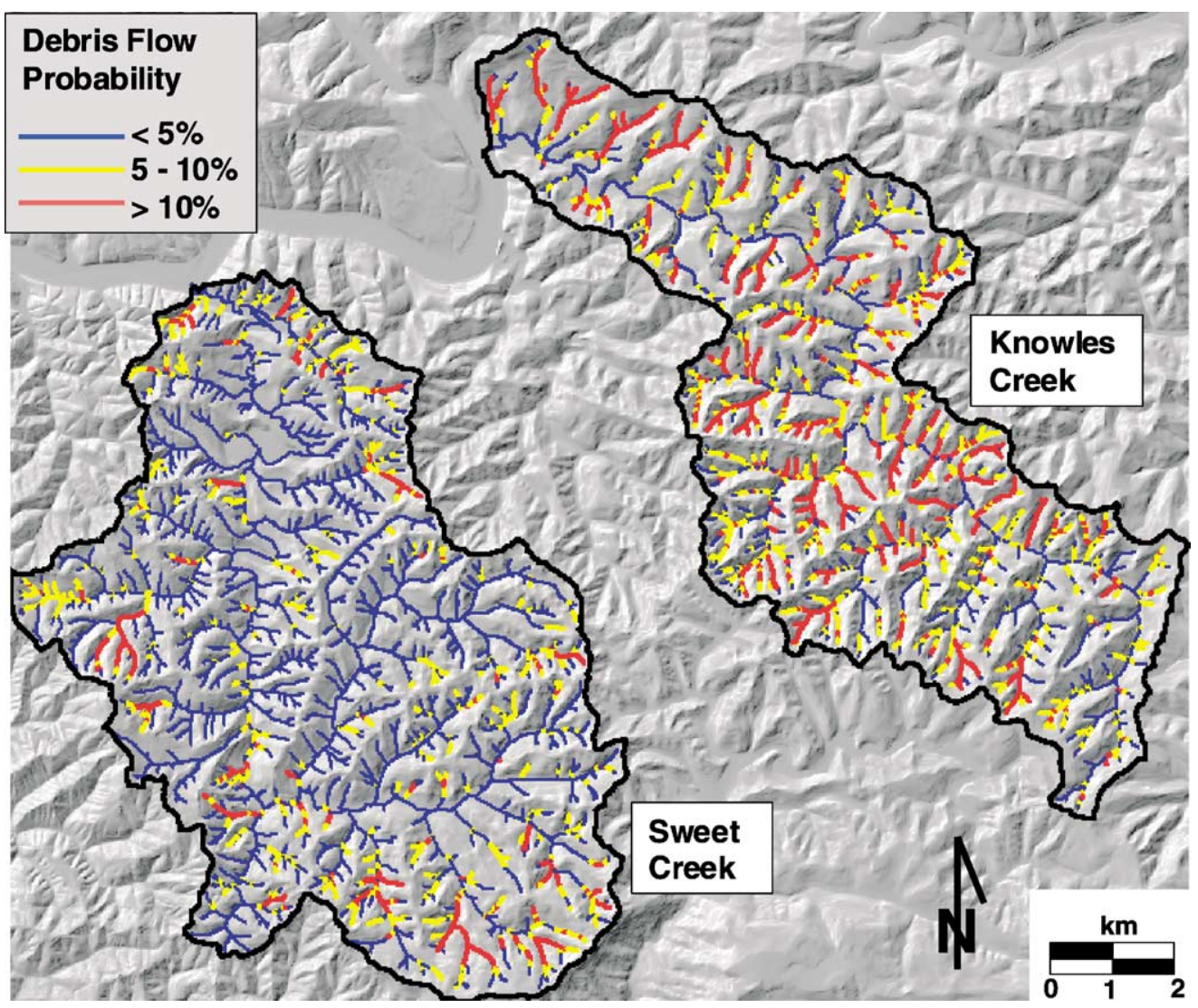

Fig. 8. The probability of debris-flow impacts, including scour and deposition, based on topography for Knowles Creek and Sweet Creek basins, Coast Range, Oregon. Topographic controls on debris-flow initiation and runout length are calibrated to debris-flow events mapped by the ODF (Robison et al., 1999) during the storm of February 1996 discussed in the text.

(see also Sprugel, 1991). Stratigraphic studies (Long et al., 1998; Millspaugh et al., 2000; Mohr et al., 2000) provide estimates over much longer time intervals and show temporal variability in average fire recurrence intervals over a range of scales (Whitlock et al., this issue).

Estimates for the size distribution of fires come from observed historical fires (e.g. Strouss et al., 1989) and from dendroecological reconstructions of past fires (Teensma, 1987; Impara, 1997). Such studies indicate positively skewed size distributions characterized by many small fires and few large ones. In long-term fire-simulation models, Benda and Dunne (1997b) characterized fire size using a negative exponential distribution and Wimberly et al. (2000) used a size distribution characterized by the inverse of the mean size.

\subsubsection{Storm climate}

The storm events that trigger erosional processes can also be characterized using probability distributions. Benda and Dunne (1997b; see also Lancaster et al., 2000), e.g. used independent negative exponential distributions of storm frequency and duration, based on work by Eagleson (1972). Miller (in USDA Forest Service, 2002) used a multiparameter distribution that accounts for correlations between frequency and duration.

These examples are calibrated to empirical rainfall records and can be used to generate a sequence of events that reproduce the stochastic nature of storms over time, but which lack spatial variability. Hydrologists must deal with issues of spatial variability as well, as shown by a long and prolific literature on the subject of spatial scaling for design precipitation 
events (e.g. US Weather Bureau, 1957; RodriguezIturbe and Mejia, 1974; Waymire et al., 1984; Rodriguez-Iturbe, 1986; Sivapalan and Blöschl, 1998; Seed et al., 1999 are a small sample). One of the primary tools used to describe this concept is the areal reduction factor (ARF), which estimates the fractional depth of point rainfall expected when considering a basin with some finite area. These curves are used with intensity-duration-frequency curves derived from statistics of individual precipitation gages to design flow structures and retention basins for catchments with some area. In general, they show that the average precipitation of a large area is less than that of a point. This is more pronounced for peaks with short duration because such peaks are typically associated with storms with small spatial extent. Besides simple spatial variability in precipitation, variability in soil water inputs caused by varying snowmelt with elevation during rain-on-snow events would also be a strong control on spatial coherence in climatic drivers to geomorphically significant events.

Conceptually, introducing ARFs into time series modeling of hillslope and channel sediment fluxes could be accomplished fairly directly using stochastic climate modeling. Note that depth-duration-frequency (DDF) curves essentially quantify the degree of concentration of rainfall in time, and one can view the ARFs as quantifying the degree to which the rainfall is concentrated in space. Parametric (e.g. Hanson et al., 1994) or resampling-based (Rajagopalan and Lall, 1999) approaches have been used to generate point rainfall depth-duration combinations, with somewhat better results from resampling. Recognizing that the ARFs essentially add another dimension to IDF curves, one could conceptualize it as a separate IDF chart for different areas, with the changes in the depth for each duration between charts given by the ARF. Depth, duration, and a randomly drawn frequency would specify an area.

There are some minor theoretical shortcomings to this approach that require attention. Many ARFs are fixed-area ARFs, when really what is needed is a storm-centered ARF. Storm-centered ARFs are generally only slightly smaller (Blöschl, 1996). In addition, very little care has been taken in understanding the seasonality of ARFs and that the ARF may change shape with return period (Blöschl, 1996). ARF curves depend strongly on how precipitation in one location is correlated with precipitation in another location. During large synoptic storms, one expects coherence over fairly large distances, e.g. several tens of kilometers. During convective precipitation events correlation may only exist on the scale of about $1 \mathrm{~km}$ (Blöschl, 1996). The fact that there is seasonality to the shape of ARF curves is important when discussing impacts of fire in forested ecosystems. Fire-induced water repellency occurring in some vegetation and soil types may lead to the formation of gullies for particular rainfall intensities (Istanbulluoglu et al., 2002). Because higher rainfall intensities are typically associated with convective storms, spatial temporal modeling of geomorphology in areas where this is important would need to consider the low spatial correlation of rainfall.

One additional challenge in applying ARFs to this modeling approach is that when there is no spatial correlation in rainfall, different points within a catchment are essentially operating independently. Thus for a given area, we may potentially need to simulate more than one storm. In the simple view adopted in earlier modeling, where the entire model domain was subjected to the same rainfall, complete correlation is assumed. When loss of correlation is considered (either from increased model domain or shorter correlation lengths), we need to consider the possibility of storm cells located in more than one part of the model domain at a time. There is no simple approach for this problem, and a range of spatio-temporal models for precipitation simulation have arisen to solve it (e.g. Waymire et al., 1984; Rodriguez-Iturbe, 1986; Seed et al., 1999; Seed, 2001). Conceptually one could also resample radar image sequences by expanding on existing vector resampling methods (e.g. Rajagopalan and Lall, 1999).

Note that the spatial scale problems outlined here are a fundamental problem with simple risk analyses applied for the US Forest Service's Burned Area Emergency Rehabilitation (BAER) program (see http://www.fs.fed.us/biology/watershed/burnareas/) which assumes uniformity of precipitation over a fire regardless of fire size. For large fires, it is unlikely that a storm will cover the whole fire, but somewhat likely that somewhere within a large fire, severe conditions will occur over a small area.

Potentially, we can consider effects of spatial variability in snowmelt with greater ease for areas where it 
is an important process in triggering large geomorphic events. Variability in snowmelt during rain-on-snow events appears at gross scales to be controlled by elevation, essentially as a surrogate for temperature. Below a given elevation, liquid precipitation combined with positive sensible latent and sensible heat to the snowpack can produce substantial soil water inputs, whereas above that elevation precipitation falls mostly as snow, and turbulent fluxes generally cool the snowpack. By generating stochastic sequences that maintain dependence structures between precipitation and temperature (Rajagopalan and Lall, 1999), we can estimate soil water input as a function of elevation from a snowmelt model in areas where the process might be important.

\section{Modeling process interactions}

\subsection{Numerical models}

As we have discussed, the factors that control sediment fluxes exhibit variability over a range of scales and quantification of these factors must accommodate variability over tens to hundreds of kilometers and hundreds, perhaps thousands, of years. Interactions that drive sediment inputs may be impossible to discern using measured spatial and temporal sequences at smaller scales (Kirchner et al., 2001), yet knowledge of factors controlling their frequency and magnitude, the spatial extent of affected stream channels, and spatial synchrony between basins is crucial to anticipating affects of land management and climate change on aquatic ecosystems (Reeves et al., 1995, Dunham et al., this issue).

To skirt the limitations imposed by observations that span only a few decades, Benda and Dunne $(1997 \mathrm{a}, \mathrm{b})$ used numerical models to examine process interactions over millennial time scales in a $200 \mathrm{~km}^{2}$ basin in western Oregon. They showed how superimposed storm and fire sequences, acting over heterogeneous topography, drive episodes of sediment delivery to a channel system. Use of a numerical model allowed them to generate event sequences over time and space scales large enough to reveal formation of distinct patterns in sediment transport and storage through a channel network and to show how such patterns emerge from the interaction of fires, storms, topography, and channel-network geometry over an entire basin. The existence and source of such patterns must still be established through field studies, but their prediction shows how process interactions over large scales may be manifest and can guide field investigations to test these ideas.

Benda and Dunne (1997a,b) illustrated the use of a "top-down" or "hierarchical" modeling approach (Murray, 2002), in which processes are described at the scale of interest (Werner, 1999). In their case, that scale was that of a channel reach-hundreds of meters-over annual time steps. They generalized processes of sediment flux and fluvial transport over these scales. This strategy seeks process descriptions at scales relevant to the system at hand, e.g. a river network, and requires parameterizations that reduce degrees of freedom to those active at that scale. This is in contrast to a reductionist strategy, which seeks to describe largescale systems from the "bottom-up", starting from the underlying processes evident at smaller scales, e.g. fluvial transport of sediment grains. Both approaches add to our understanding of natural systems, but hierarchical models are needed to explore interactions at scales pertinent to the frequency, magnitude, spatial extent, and synchrony of channel disturbance.

Hierarchical models have a variety of uses. They provide a means of visualizing concepts over basin scales. Benda et al. (1998) used model results to illustrate effects of basin size and position in a channel network on sediment yields and probability distributions of sediment storage in channel reaches. The USDA Forest Service (2002) used model animations to show how fires, storms, landsliding, and fluvial transport can interact to produce variability in large woody debris and sediment storage through a river network.

These models can be used to explore the consequences of process interactions. Benda and Dunne (1997a) predicted that the overlapping effects of fires and storms drive episodic influxes of sediment to channels that initiate pulses of sediment transport through the network. In contrast, Lancaster et al. (2000) predicted that effects of woody debris on debris-flow runout distance cause low-order basins to act as long-term sediment stores that gradually meter sediment out to larger channels, thereby diffusing the capacity for episodes of landsliding to generate pulses of fluvial transport through the high-order network. Differences in model predictions highlight the 
potential role of specific factors and motivate field measurements to test these hypotheses.

As experience with these types of models grows, their utility will expand. They will be used as exploratory tools to evaluate the influence that differences in topography or changes in climate or fire regime might have on sediment fluxes and associated channel disturbances. They will be used to evaluate the time scales of response and recovery and the role of history in setting channel and basin responses to storm and fire events. Importantly, they will be used in scenario testing to evaluate the likely consequences of different management strategies (Dunne et al., 2001).

\subsection{Data requirements}

Two general types of information are required to build numerical models: (1) data to characterize the driving events, e.g. fires and storms, and (2) data to characterize controls on consequent erosional events. The models referenced here lack several important factors: characterization of fire distributions from stand-age mapping as used by Benda et al. (1998) misses potentially important aspects of fire intensity; use of spatially uniform storm events misses important aspects of spatial variability in storm intensity; and currently available digital elevation data cannot resolve small-scale topographic controls on gully initiation and landsliding. However, progress is being made on all fronts. Aerial mapping of fire intensity provides information on fire size distributions and field mapping of associated effects (e.g. changes in soil infiltration capacity) links fire intensity to consequent impacts. Doppler radar may provide a means of characterizing the spatial variability of rainfall intensity associated with single storms and provide information to estimate the size and frequency distribution of storm events. New methods for remotely sensed elevation measurements, such as laser altimetry (LIDAR), can provide high-resolution topographic data. The next challenge may be to find the resources to use available data.

Currently, basin-scale models can produce temporally and spatially distributed estimates of sediment flux. Process-based models to translate estimates of sediment flux and storage to temporal and spatial predictions of biologically pertinent channel characteristics, such as substrate texture (Dietrich et al., 1989;
Buffington and Montgomery, 1999; Lisle et al., 2000) or pool extent (USDA Forest Service, 2002) must still be incorporated. Data to characterize the consequences to channels of changes in sediment volume and to characterize biological responses to those changes are essential for using numerical models to interpret and infer the consequences of past and future changes in fire regime, climate, and land management.

\section{Conclusions}

Sediment fluxes and consequent stream-channel disturbances are driven by process interactions over time periods spanning centuries and spatial scales spanning entire river basins. Methods for data collection and analyses over these scales are being actively developed, spurred by the realization that land-management practices, coupled with changes in climate, can dramatically influence rates of sediment delivery to stream channels. Stratographic and sedimentological studies (e.g. Meyer and Pierce, this issue) are greatly expanding records of past sediment-flux events and point to strong climatic controls and large variations across regions. To anticipate the consequences of land management, fire suppression, and climate change, we require quantitative characterizations of the processes that drive sediment fluxes and of the factors that control the spatial and temporal patterns of sediment delivery to stream channels. The stochastic and heterogeneous nature of these processes leads us to probabilistic descriptions and to development of analytical methods that use probabilistic parameterizations. Predictive tools must also deal with the effects of past events. These requirements have lead to development of numerical models that can simulate process interactions over large temporal and spatial scales. As experience with these types of models accumulates, they have the potential to provide a useful analysis tool, offering a spatial and temporal context for interpretation of field observations and predictions that can be tested with field measurements.

\section{Acknowledgements}

The landslide density and topographic control on debris-flow probability analyses reported on here were 
done with support and assistance from the Coastal Landscape Analysis and Modeling study through the US Forest Service, Pacific Northwest Research Station, Forest Sciences Laboratory, in Corvallis, Oregon. Jim Paul and Jason Hinkle with the Oregon Department of Forestry were also very helpful in providing data from the 1996 storm study. We thank Christine May, who provided data from her thesis work and prompted many helpful discussions. Thanks to Kelly Christiansen and Dave Nagel for assisting with graphics production and to Jack King for aerial photograph interpretation and mapping. We greatly appreciate reviews by David Tarboton, John Buffington, and an anonymous reviewer, which served to improve an earlier version of this paper.

\section{References}

Agee, J.K., 1993. Fire Ecology of Pacific Northwest Forests. Island Press, Washington, DC.

Agee, J.K., Flewelling, R. (Eds.), 1983. A Fire Cycle Model Based on Climate for the Olympic Mountains, Washington. In: Proceedings of Seventh Conference on Fire and Forest Meteorology. American Meteorology Society, Boston, 7, pp. 32-37.

Agee, J.K., Finney, M., de Gouvenain, R., 1990. Forest fire history of Desolation Peak, Washington. Can. J. For. Res. 20, 350-356.

Bear, J., 1972. Dynamics of Fluids in Porous Media. Elsevier, New York.

Benda, L.E., 1990. The influence of debris flows on channels and valley floors in the Oregon Coast Range, USA. Earth Surf. Process. Landforms 15, 457-466.

Benda, L.E., Cundy, T.W., 1990. Predicting deposition of debris flows in mountain channels. Can. Geotechnol. J. 27, 409-417.

Benda, L.E., Dunne, T., 1997a. Stochastic forcing of sediment routing and storage in channel networks. Water Resour. Res. $33,2865-2880$.

Benda, L.E., Dunne, T., 1997b. Stochastic forcing of sediment supply to channel networks from landsliding and debris flow. Water Resour. Res. 33, 2849-2863.

Benda, L.E., Miller, D.J., Dunne, T., Reeves, G.H., Agee, J.K., 1998. Dynamic landscape systems. In: Naiman, R.J., Bilby, R.E. (Eds.), River Ecology and Management. Springer, New York, pp. 261-288.

Blöschl, G., 1996. Scale and Scaling in Hydrology. Weiner Mitteilungen Wasser Abwasser Gewasser, Wien.

Brardinoni, F., 2001. Identification of natural and logging-related landslides in the Capilano River Basin (Coastal British Columbia): a comparison between remotely sensed survey and field survey. Masters Thesis. The University of British Columbia, Vancouver, BC.
Buffington, J.M., Montgomery, D.R., 1999. Effects of sediment supply on surface textures of gravel-bed rivers. Water Resour. Res. 35, 3523-3530.

Bush, G., McConnel, C., Cloyd, C., Musser, K., Metzger, B., Plumley, H., 1997. Assessment of the effects of the 1996 flood on the Siuslaw National Forest. USDA Forest Service, Siuslaw National Forest, Corvallis, OR.

Caine, N., 1980. The rainfall intensity-duration control of shallow landslides and debris flows. Geografiska Annaler. A 62, 23-27.

Cannon, S.H., 2001. Debris-flow generation from recently burned watersheds. Environ. Eng. Geosci. 7, 321-341.

Cenderelli, D.A., Kite, J.S., 1998. Geomorphic effects of large debris flows on channel morphology at North Fork Mountain, Eastern West Virginia, USA. Earth Surf. Process. Landforms 23, 1-19.

Chernick, M.R., 1999. Bootstrap Methods: A Practitioner's Guide. Wiley, New York.

Coates, R., Collins, L., 1984. Streamside landsliding and channel change in a suburban forested watershed: effects of an extreme event. In: Proceedings of the Symposium on Effects of Forest Land Use on Erosion and Slope Stability. East-West Center, Honolulu, pp. 155-164.

Coho, C., Burges, S.J., 1993. Dam-break floods in low-order mountain channels of the Pacific Northwest. Water Resources Series, Technical Report No. 138. Department of Civil Engineering, University of Washington, Seattle, WA.

Dietrich, W.E., Dunne, T., 1978. Sediment budget for a small catchment in mountainous terrain. Z. Geomorph. Suppl. Bd. 29, 191-206.

Dietrich, W.E., Kirchner, J.W., Ikeda, H., Iseya, F., 1989. Sediment supply and the development of the coarse surface layer in gravel-bedded rivers. Nature 340, 215-217.

Dietrich, W.E., Wilson, C.J., Montgomery, D.R., McKean, J., Bauer, R., 1992. Erosion thresholds and land surface morphology. Geology 20, 675-679.

Dietrich, W.E., Bellugi, D., de Asua, R.R., 2001. Validation of the shallow landslide model, SHALSTAB, for forest management. In: Wigmosta, M.S., Burges, S.J. (Eds.), Land Use and Watersheds. American Geophysical Union, Washington, DC, pp. 195-227.

Dragovich, J.D., Brunengo, M.J., Gerstel, W.J., 1993a. Landslide inventory and analysis of the Tilton River-mineral Creek area, Lewis county, Washington. Part 1. Terrain and Geologic Factors. Wash. Geol. 21, 9-18.

Dragovich, J.D., Brunengo, M.J., Gerstel, W.J., 1993b. Landslide inventory and analysis of the Tilton River-mineral Creek area, Lewis county, Washington. Part 2. Soils, harvest age, and conclusions. Wash. Geol. 21, 18-30.

Dunham, J.B., Rieman, B.E., 1999. Metapopulation structure of bull trout: influences of physical, biotic, and geometrical landscape characteristics. Ecol. Appl. 9, 642-655.

Dunne, T., 1998. Critical data requirements for prediction of erosion and sedimentation in mountain drainage basins. J. Am. Water Resour. Assoc. 34, 795-808.

Dunne, T., Agee, J.K., Beissinger, S., Dietrich, W.E., Gray, D., Power, M., Resh, V., Rodrigues, K., 2001. A scientific basis for the prediction of cumulative watershed effects. University of 
California Wildland Resource Center Report No. 46. University of California Wildland Resource Center, Berkeley, CA.

Eagleson, P.S., 1972. Dynamics of flood frequency. Water Resour. Res. 8, 878-898.

Everest, F.H., Meehan, W.R., 1981. Forest management and anadromous fish habitat productivity. Trans. North Am. Wildl. Nat. Resour. Conf. 46, 521-530.

Everest, F.H., Beschta, R.L., Scrivener, J.C., Koski, K.V., Sedell, J.R., Cederholm, C.J., 1987. Fine sediment and salmonid production: A Paradox. In: Salo, E.O., Cundy, T.W. (Eds.), Streamside Management: Forestry and Fishery Interactions. College of Forest Resources, University of Washington, Seattle, WA, USA, pp. 98-142.

Grant, G.G., Swanson, F.J., 1995. Morphology and processes of valley floors in mountain streams, Western Cascades, Oregon. In: Costa, J.E., Miller, A.J., Potter, K.W., Wilcock, P.R. (Eds.), Natural and Anthropogenic Influences in Fluvial Geomorphology, Geophysical Monograph 89. American Geophysical Union, Washington, DC, pp. 83-101.

Grant, G.E., Swanson, F., Wolman, M.G., 1990. Pattern and origin of stepped-bed morphology in high-gradient streams, Western Cascades, Oregon. GSA Bull. 102, 340-352.

Gresswell, R.E., 1999. Fire and aquatic ecosystems in forested biomes of North America. Trans. Am. Fish. Soc. 128, 193-221.

Hack, J.T., Goodlett, J.C., 1960. Geomorphology and Forest ecology of a Mountain Region in the Central Appalachians. US Geological Survey Professional Paper 347, 66 pp.

Hall, D.E., Long, M.T., Remboldt, M.D. (Eds.), 1994. Slope Stability Reference Guide for National Forests in the United States. United States Department of Agriculture, Forest Service, Washington, DC.

Hammond, C., Hall, D., Miller, S., Swetik, P., 1992. Level 1 Stability Analysis (LISA) Documentation for Version 2.0. General Technical Report INT-285. United States Department of Agriculture, Forest Service, Intermountain Research Station, Ogden, Utah.

Hanson, C.L., Cumming, K.A., Woolhiser, D.A., Richardson, C.W., 1994. Microcomputer Program for Daily Weather Simulations in the Contiguous United States. ARS-114. Agricultural Research Service, US Department of Agriculture, Washington, DC.

Harvey, A.M., 1991. The influence of sediment supply on the channel morphology of upland streams: Howgill Fells, Northwest England. Earth Surf. Process. Landforms 16, 675-684.

Hogan, D.L., Bird, S.A., Rice, S., 1998. Stream channel morphology and recovery processes. In: Hogan, D.L., Tschaplinski, P.J., Chatwin, S. (Eds.), Carnation Creek and Queen Charlotte Islands Fish/Forestry Workshop: Applying 20 Years of Coast Research to Management Solutions. Land Management Handbook 41. Crown Publications, Victoria, BC, pp. $77-96$.

Hovius, N., Stark, C.P., Allen, P.A., 1997. Sediment flux from a mountain belt derived by landslide mapping. Geology 25, 231-234.

Impara, P.C., 1997. Spatial and temporal patterns of fire in the forests of the Central Oregon Coast Range. Ph.D. Oregon State University, Corvallis, OR.
Istanbulluoglu, E., Tarboton, D.G., Pack, R.T., Luce, C.H., 2002. A probabilistic approach for channel initiation. Water Resour. Res. 38, 1325.

Iverson, R.M., 2000. Landslide triggering by rain infiltration. Water Resour. Res. 36, 1897-1910.

Iverson, R.M., Schilling, S.P., Vallance, J.W., 1998. Objective delineation of lahar-inundation hazard zones. Geol. Soc. Am. Bull. 110, 972-984.

Keane, R.E., Ryan, K., Running, S.W., 1996. FIRE-BGC-a mechanistic ecological process model for simulating fire succession on coniferous forest landscapes of the Northern Rocky Mountains. INT-RP-484. USDA Forest Service, Fort Collins, CO.

Kirchner, J.W., Finkel, R.C., Riebe, C.S., Granger, D.E., Clayton, J.L., King, J.G., Megahan, W.F., 2001. Mountain erosion over 10 year, 10 k.y., and 10 m.y. time scales. Geology 29, 591-594.

Lancaster, S.T., Hayes, S.K., Grant, G.E., 2000. Modeling sediment and wood storage and dynamics in small mountainous watersheds. In: Dorava, J.M., Montgomery, D.R., Palcsak, B.B., Fitzpatrick, F.A. (Ed.), Geomorphic Processes and Riverine Habitat, vol. 4. American Geophysical Union, Washington, DC, pp. $85-102$.

Larsen, M.C., Simon, A., 1993. A rainfall intensity-duration threshold for landslides in a humid-tropical environment, Puerto Rico. Geografiska Annaler. 75, 13-23.

Lisle, T.E., Nelson, J.M., Pitlick, J., Madej, M.A., Barkett, B.L., 2000. Variability of bed mobility in natural, gravel-bed channels and adjustment to sediment load at local and reach scales. Water Resour. Res. 36, 3743-3755.

Long, C.J., Whitlock, C., Bartlein, P.J., Millspaugh, S.H., 1998. A 9000-year fire history from the Oregon coast range, based on a high-resolution charcoal study. Can. J. For. Res. 28, 774-787.

Madej, M.A., 1990. Changes in channel-stored sediment, redwood creek, Northwestern California, 1947-1980. In: Nolan, K.M., Kelsey, H.M., Marron, D.C. (Eds.), Geomorphic Processes and Aquatic Habitat in the Redwood Creek Basin, Northwestern California. US Geological Survey Professional Paper 1454, Washington, DC.

Madej, M.A., Ozaki, V., 1996. Channel response to sediment wave propagation and movement, Redwood Creek, California, USA. Earth Surf. Process. Landforms 21, 911-927.

May, C.L., 1998. Debris flow characteristics associated with forest practices in the Central Oregon Coast range. Masters. Oregon State University, Corvallis, OR.

May, C.L., 2001. Spatial and temporal dynamics of sediment and wood in headwater streams in the Central Oregon Coast range. Ph.D. Oregon State University, Corvallis, OR.

May, C.L., 2002. Debris flows through different forest age classes in the central Oregon Coast Range. J. Am. Water Resour. Assoc. 38, 1-17.

McKenzie, D., Peterson, D.L., Alvarado, E., 1996. Extrapolation problems in modeling fire effects at large spatial scales: a review. Int. J. Wildl. Fire 6, 165-176.

Meyer, G.A., Wells, S.G., Jull, A.J.T., 1995. Fire and alluvial chronology in Yellowstone National Park: climatic and intrinsic controls on Holocene geomorphic processes. Geol. Soc. Am. Bull. 107, 1211-1230. 
Meyer, G.A., Pierce, J.L., Wood, S.H., Jull, A.J.T., 2001. Fire, storms, and erosional events in the Idaho batholith. Hydrol. Process. 15, 3025-3038.

Middleton, G.V., Wilcock, P.R., 1994. Mechanics in the Earth and Environmental Sciences. Cambridge University Press, Cambridge.

Miller, D.J., Benda, L.E., 2000. Effects of punctuated sediment supply on valley-floor landforms and sediment transport. Geol. Soc. Am. Bull. 112, 1814-1824.

Miller, D.J., Burnett, K.M., Christiansen, K., Clarke, S., 2002. A simple model for regional prediction of debris flow impacts. In: http://www.fsl.orst.edu/clams/, Projects, Broad-scale Models of Landslides and Debris Flows.

Millspaugh, S.H., Whitlock, C., Bartlein, P.J., 2000. Variations in fire frequency and climate over the past 17,000 year in central Yellowstone National Park. Geology 28, 211-214.

Mohr, J.A., Whitlock, C., Skinner, C.N., 2000. Postglacial vegetation and fire history, eastern Klamath mountains, California, USA. The Holocene 10, 587-601.

Montgomery, D.R., Buffington, J.M., 1998. Channel processes, classification, and response. In: Naiman, R.J., Bilby, R.E. (Eds.), River Ecology and Management. Springer, New York, pp. 13-42.

Montgomery, D.R., Dietrich, W.E., 1994. A physically based model for the topographic control on shallow landsliding. Water Resour. Res. 30, 1153-1171.

Montgomery, D.R., Schmidt, K.M., Greenberg, H.M., Dietrich, W.E., 2000. Forest clearing and regional landsliding. Geology 28, 311-314.

Murray, B.A., 2002. Seeking explanation affects numerical modeling strategies. EOS, Trans. Am. Geophys. Union 83, 418-419.

Nakamura, F., Maita, H., Araya, T., 1995. Sediment routing analyses based on chronological changes in hillslope and riverbed morphologies. Earth Surf. Process. Landforms 20, 333-346.

Nolan, K.M., Marron, D.C., 1988. Stream-channel response to the storm in the Santa Cruz mountains. In: Ellen, S.D., Wieczorek, G.F. (Eds.), Landslides, Floods, and Marine Effects of the Storm of January 3-5, 1982, in the San Francisco Bay Region, California. US Geological Survey Professional Paper 1434. US Geological Survey, Washington, DC.

Nolan, K.M., Marron, D.C., 1990. History, causes, and significance of changes in the channel geometry of Redwood Creek, northwestern California, 1926-1982. In: Nolan, K.M., Kelsey, H.M., Marron, D.C. (Eds.), Geomorphic Processes and Aquatic Habitat in the Redwood Creek Basin, Northwestern California. US Geological Survey Professional Paper 1454. US Geological Survey, Washington, DC.

Ohmann, J.L., Gregory, M.J., 2002. Predictive mapping of forest composition and structure with direct gradient analysis and nearest neighbor imputation in coastal Oregon, USA. Can. J. For. Res. 32, 725-741.

O'Laughlin, E.M., 1986. Prediction of surface saturation zones in natural catchments by topographic analysis. Water Resour. Res. 22, 794-804.

Oregan State University, 1996. Summary of precipitation for central Oregon Coast Range, October 1995 to April 1996. COPE Report 9 (4). Oregon State University, Corvallis.
Pabst, R.J., Spies, T.A., 2001. Ten years of vegetation succession on a debris-flow deposit in Oregon. J. Am. Water Resour. Assoc. 37, 1693-1708.

Pyles, M.R., Froehlich, H.A., 1987. Discussion of "Rates of Landsliding as Impacted by Timber Management Activities in Northwestern California". Bull. Assoc. Eng. Geol. 24, 425431.

Rajagopalan, B., Lall, U., 1999. A $k$-nearest-neighbor simulator for daily precipitation and other weather variables. Water Resour. Res. 35, 3089-3101.

Reeves, G.H., Benda, L.E., Burnett, K.M., Bisson, P.A., Sedell, J.R., 1995. A disturbance-based ecosystem approach to maintaining and restoring freshwater habitats of evolutionarily significant units of anadromous salmonids in the Pacific Northwest. In: Nielson, J.L., Powers, D.A. (Eds.) Evolution and the Aquatic Ecosystem: Defining Unique Units in Population Conservation, American Fisheries Society Symposium 17. American Fisheries Society, Bethesda, MD, USA, pp. 334-349.

Reneau, S.L., Dietrich, W.E., Donahue, D.J., Jull, A.J.T., Rubin, M., 1990. Late quaternary history of colluvial deposition and erosion in hollows, central California Coast Ranges. Geol. Soc. Am. Bull. 102, 969-982.

Robison, G.E., Mills, K.A., Paul, J., Dent, L., Skaugset, A., 1999. Storm Impacts and Landslides of 1996: Final Report 4. Oregon Department of Forestry.

Rodriguez-Iturbe, I., 1986. Scale of fluctuation of rainfall models. Water Resour. Res. 22, 15S-37S.

Rodriguez-Iturbe, I., Mejia, J.M., 1974. On the transformation from point rainfall to areal rainfall. Water Resour. Res. 10, 729-735.

Schmidt, K.M., 1999. Root strength, colluvial soil depth, and colluvial transport on landslide-prone hillslopes. Ph.D. Dissertation. University of Washington, Seattle.

Seed, A.W., 2001. Theory and measurements of the distribution of rainfall in space and time. In: Proceedings of the MODSIM 2001, International Congress on Modelling and Simulation, Canberra, Australia, December 10-13. Modelling and Simulation Society of Australia and New Zealand.

Seed, A.W., Srikanthan, R., Menabde, M., 1999. A space and time model for design storm rainfall. J. Geophys. Res. 104, 31623-31630.

Sidle, R.C., Pearce, A.J., O'Loughlin, C.L., 1985. Hillslope Stability and Land Use. American Geophysical Union, Washington, DC.

Sivapalan, M., Blöschl, G., 1998. Transformation of point rainfall to areal rainfall: intensity-duration-frequency curves. J. Hydrol. 204, 150-167.

Sprugel, D.G., 1991. Disturbance, equilibrium, and environmental variability: What is 'natural' vegetation in a changing environment? Biol. Conserv. 58, 1-18.

Strouss, D., Bednar, L., Mees, R., 1989. Do one percent of forest fires cause ninety-nine percent of the damage? For. Sci. 35, 319-328.

Swanson, F.J., 1981. Fire and geomorphic processes. In: Fire Regimes and Ecosystem Properties, General Technical Report 
W0-26. US Department of Agriculture Forest Service, Washington, DC, pp. 401-420.

Swanson, F.J., Kratz, T.K., Caine, N., Woodmansee, R.G., 1988. Landform effects on ecosystem patterns and processes. BioScience 38, 92-98.

Taylor, G., 1997a. Causes of the flood and a comparison to other climate events. In: Ruff, J.D. (Eds.), The Pacific Northwest Floods of February 6-11, 1996: Proceedings of the Pacific Northwest Water Issues Conference. American Institute of Hydrology, St. Paul, Minnesota, USA, pp. 3-7.

Taylor, G.H., 1997b. The Great Flood of 1996, Oregon Climate Service.

Teensma, P.D.A., 1987. Fire history and fire regimes of the central western Cascades of Oregon. Ph.D. University of Oregon, Eugene, OR.

US Weather Bureau, 1957. Rainfall intensity-frequency regime 1. The Ohio valley 2. Southeastern United States. Technical Paper No. 29. US Department of Commerce, Washington, DC.

USDA Forest Service, 2002. Landscape dynamics and forest management. Gen. Tech. Rep. RMRS-GTR-101CD. US
Department of Agriculture, Forest Service, Rocky Mountain Research Station, Fort Collins, CO.

Van Wagner, C.E., 1978. Age-class distribution and the forest fire cycle. Can. J. For. Res. 8, 220-227.

Waymire, E., Gupta, V.K., Rodriguez-Iturbe, I., 1984. A spectral theory of rainfall intensity at the meso-"Beta" scale. Water Resour. Res. 20, 1453-1465.

Werner, B.T., 1999. Complexity in natural landform patterns. Science 284, 102-104.

Wimberly, M.C., 2002. Spatial simulation of historical landscape patterns in coastal forests of the Pacific Northwest. Can. J. For. Res. 32, 1316-1328.

Wimberly, M.C., Spies, T.A., Long, C.J., Whitlock, C., 2000. Simulating historical variability in the amount of old forests in the Oregon Coast Range. Conserv. Biol. 14, 167-180.

Wohl, E.E., Pearthree, P.P., 1991. Debris flows as geomorphic agents in the Huachuca Mountains of southeastern Arizona. Geomorphology 4, 273-292.

Zevenbergen, L.W., Thorne, C.R., 1987. Quantitative analysis of land surface topography. Earth Surf. Process. Landforms 12, $47-56$. 